\title{
The Role of Abadina Media Resource Centre in Bringing Novelty and Creativity to School Library Services in Nigeria
}

\author{
Fadekemi Omobola Oyewusi, Ph.D., Acting Director \\ Abadina Media Resource Centre, Faculty of Education, University of Ibadan, Nigeria. \\ Telephone: +2348062457423 \\ E-mail: fdkwusi@yahoo.com
}

\begin{abstract}
This article looks into the role of Abadina Media Resource Centre in expanding school library services in Nigeria. The article revealed the novelty seen in the functions of the Centre especially in the training of qualified personnel for the positions of teacher-librarians, media specialists, reading teachers and other school media personnel in pre-primary, primary and post-primary institutions in Nigeria and organizing of programmes relevant to reading and library use for Nigerian Children. In addition, core activities of the Centre were highlighted and challenges facing the school library media centre were also discussed. Abadina Media Resource Centre has developed training programmes to produce qualified personnel that will run virile school media programmes in Nigerian schools, teach school media and conduct scientific and reliable researches to extend the frontiers of knowledge in the field.
\end{abstract}

\section{Introduction}

It is a pleasure to share with us some of the novelty and creativity brought into school library services in Nigeria by Abadina Media Resource Centre (AMRC), University of Ibadan, Nigeria. As we all know, no child (especially in developing countries) can afford to purchase all books he require throughout his school years and this necessitates the need for providing library resources so that he is not placed at the disadvantage of using high quality books for lack of funds. For this reason, AMRC was established to provide evidence-based library services, materials and educational resources to primary school children, secondary school children, young adults and provide research platform for researchers interested in doing research on school library services, literacy and reading among others in Nigeria. A good School Library Media Centre (SLMC) requires that trained library personnel be employed to provide quality information services to the users. The University of Ibadan in 2006 approved for the Centre the training of qualified personnel for the positions of teacher-librarians, media specialists, reading teachers and other school media personnel in pre-primary, primary and post-primary institutions in Nigeria. School media programmes are designed to plays a key role in developing school effectiveness and assist learners to grow in their ability to employ a variety of media to find, evaluate, use and generate information. However, Nigerian schools lack qualified school media specialists to develop and administer school media programmes. Hence, the need for the Centre to focus on training of qualified school library media specialists in Nigeria. 
As we know, the school is a gateway to knowledge and plays an important role in building up a love for reading and the school library is integral to this educational process (Mahajan, 2010). The school library provides information and ideas that are fundamental to functioning successfully in today's information and knowledge-based society. "The school library equips students with life-long learning skills and develops the imagination, enabling them to live as responsible citizens" (IFLA/UNESCO, 2006). According to IFLA and UNESCO,

The school library should provide learning services, books and resources that would enable all members of the school community to become critical thinkers and effective users of information in all formats and media. A school library is more than just a room filled with books, this library engages in creativities efforts that supports, engages and stimulates learning and development.

The school library's role is to help create confident, enthusiastic readers, and to engage children in lifelong learning. This article would dwell on enlightening us on the role of Abadina Media Resource Centre in bringing novelty and creativity to school library services in Nigeria despite the economic recession. This would also be done through the use of pictures to reveal past and present activities of the Centre.

\section{History of Abadina Media Resource Centre}

Abadina Media Resource Centre (AMRC) was established by the Senate of the University of Ibadan in 1974 as an autonomous research and public service unit within the Faculty of Education, University of Ibadan Nigeria. The Centre opened its services to users which includes school children, teachers and adults working with children in January, 1975. The Public service unit of the Centre offers library services to the pupils in both primary and secondary schools. The number of users since inception in 1975 amounted to 5,203 with the average collection of 6,055. Average number of users per day is between 16-25 patrons and about 80 users per week. The centre opens between 8.00 am and 6.00 pm during the week while it operates between $9.00 \mathrm{am}$ and $1.00 \mathrm{pm}$ on Saturdays. Parents and guardians within and outside the University do register their children and wards paying between N200 to N1000 depending on the category the children belong to which is valid for a period of one year. The teachers are also allowed to use the collection in the teaching-learning programmes. Materials needed for the Nigerian educational system have been carefully selected, systematically arranged using the Dewey Decimal Classification Scheme and stored for retrieval and dissemination of information as at when necessary.

The Centre coordinates the activities of other school library media resource centres in Nigeria. In addition, the Centre provides resources needed to prepare adequately for the TOEFL, GRE, SAT, GMAT and other related examination.

The programme of the Centre at inception comprised mainly the establishment and running of a school library media centre as a model for Nigerian schools and development of research programmes. The Centre was created to perform the following roles among others:

- Establishing the reading pattern of the Nigerian primary and secondary school students.

- Developing library use education syllabus to teach library use skills to students. 
- Compiling lists of books and non-book media for use of school libraries in collection development.

- Conducting research into children's literature and school library problems.

- Conducting and promoting educational research into books and learning resources production for Nigerian schools.

- Organising workshops and conferences for teacher-librarians, school librarians and writers of children's books.

\section{Functions of the Centre}

The approved functions for the Centre as stipulated in are to:

- conduct and promote educational research into books and learning resources management and their production for primary, secondary and tertiary levels of education.

- conduct courses of study for school librarians, teacher- librarians, children's librarians, library assistants and courses in School Media for media specialists in primary and postprimary institutions (AMRC Prospectus, 2011).

- through the establishment of model resource centre in Nigeria, and through the use of books and other media, inculcate the love and desire for books in children.

- design and promote curricula for library use education in the Nigerian schools system thereby equipping children with appropriate learning skills for life-long learning.

- provide advisory and consultancy services to government, schools, colleges and other organizations in relation to management of school libraries/media resource centres as may be requested from time to time.

- organise seminars, workshops, conferences, demonstrations and exhibitions on school librarianship, children's literature and other learning resource materials and their management.

As part of its efforts in bringing novelty and creativity to school library services in Nigeria, the Centre is sub-divided into five operating units as follow:

- $\quad$ Bibliographic and Reading Development unit

- Consultancy and Outreach programme unit

- $\quad$ Research and Postgraduate programme unit

- $\quad$ School Library Media Resource unit and

- $\quad$ Audiovisual media and e-learning unit

\section{Activities Engaged in by the Centre}

AMRC has been involved in the activities listed below

- Readers Services: The Centre acquires and organises books and non-book materials on all areas of knowledge that are relevant to the Nigerian school curriculum for the use of children for general information and recreational reading. Materials could either be used within the centre or borrowed. To facilitate the effective use of the multimedia collection, 
orientation programmes are organised for new teachers and pupils as well as other newly registered readers at the beginning of each school year (Elaturoti, 2007). The appropriate library use skills are also taught to all users on regular basis

- Saturday Story Hour: The Centre organises story hour for children on Saturdays between 10.00 a.m. and 11.00 a.m.

- Consultancy Services: The Centre offers a range of consultancy services to the public on such matters as establishment of school library media centres, organisation of learning resources, development of children's literature, and resource materials training of school library personnel, and others on the use of media in education. The Centre organises on regular basis, workshops and conferences to promote the development of libraries and learning resources in schools and to train school library personnel.

- Research: The Centre has produced a number of publications based on research projects carried out at the Centre from inception. The Centre also serves as the hub for coordinating activities relating to the publishing of the Nigerian School Library Association journal on a yearly basis. Other publications include:

- $\quad$ Manual for Nigerian School Libraries (1978).

- $\quad$ Syllabuses for effective Use of Books and Libraries (1978).

- $\quad$ A Select List of Books for Children (1981).

- $\quad$ Effect of Library use Education Programme on Academic Achievement and Social Development of the Primary School Child (1986).

- $\quad$ Approach to Organisation of Learning Resources in School Library Media Centre and other Libraries (2009)

- Loan of learning resources to schools: Teachers in nursery, primary and secondary schools borrow learning resources for use in the classroom while registered adult users working with children also borrow learning resources from the centre.

- Production of Instructional media: To provide the relevant resource materials for the school curriculum, efforts are being made to produce local instructional media which teachers could borrow for use in classrooms.

- Children's and Socio-Cultural Programme: The Centre organises drama groups, science club and other hobby groups for children. The center also organizes children's carnival to develop the talents of the children in drama, poetry and other creative educational activities.

- Coordinating School Library Programme nationwide: The centre provides the Secretariat for Nigerian School Library Association and coordinates its annual conferences from 1977 to date.

- Counseling: The Centre staff takes interest in the welfare of the children that uses the library. This has led to counseling of the children and their parents on diverse matters ranging from educational to health issues.

Note

In recent years, some of the points highlighted above have been difficult to achieve successfully due to financial constraints. Although with meager funds, the Centre organised a seminar on "how to cultivate reading culture" for three hundred Nigerian school children between ages 9 15 years from 30 schools within Ibadan on October 2011. (See appendix for pictures) 


\section{Abadina Media Resource Centre Training Programme}

Since 2006, the Centre has added teaching of school media courses to its programmes to produce qualified school library media specialists, the programmes include Diploma in School Media, Master's in Media Resource Management, Master's in School Media and Master of Philosophy, PhD in School Media. These training programmes have made the Centre a full fledged academic Centre within the University. Studies conducted on availability and use of relevant learning resources in support of the school curricula have revealed that there is a dearth of relevant and suitable learning resources for implementing the curricula in Nigerian schools. There is also a shortage of personnel such as teacher-librarians, media specialists and readingteachers to develop virile media programmes for effective implementation of the curricula in the Nigerian schools' system.

\section{Diploma in School Media}

The programme is run on part-time for a period of 2 academic sessions. The entry qualifications are four credits in Senior School Certificate Examination (SSCE), GCE or NECO. Matured candidates with lesser papers at SSCE/GCE/NECO or Teachers Grade Two Certificate holders with a minimum of five years working experience in recognized libraries/institutions could be admitted (Elaturoti, 2007). Also holders of the Nigeria Certificate of Education (NCE) that want to work as media specialists in schools are qualified for admission. The Diploma programme is a combination of courses in LIS (46 units), education (8 units) and language (6 units). The courses are either compulsory (22 units), required 22 units) or elective (16 units). There are a total of 44 courses (taken within a period of 3 years) that are either compulsory or required, made up of LIS (34 units), education (6 units) and reading (4 units). These are courses students must take and score $40 \%$ for the compulsory and $35 \%$ for the required courses. The elective courses are only 16 units made up of LIS (12 units), education (2 units) and reading (2 units) courses. For the award of the Diploma certificate, a candidate should pass 40 units including all the compulsory courses.

\section{Professional Master in Media Resource Management (MMRM)}

The MMRM is to produce professionally qualified media specialists to run the school library media centres established in schools at the Local Government Education Authorities (LGEA), state and national levels as well as the resource centres for the distance learning programmes and the media houses among others (Elaturoti, 2007). Eligible candidates for the programme are university degree and Higher National Diploma (HND) Certificate holders in any discipline. Registration for the programme could be on full-time or part-time basis. A minimum of three and maximum of five semesters are required for full-time study and a minimum of five and maximum of seven semesters for the part-time study (Elaturoti, 2007). The programme is made up of course work (50 units), practical work (4 units), and research projects (6 units) making a total of 60 units. The 50 units of course work consist of LIS (36 units), education (8 units), reading (4 units), and communication ( 2 units). Of the 50 units course work, 26 units are either compulsory or required for LIS, 6 units for education, 2 units for reading and 2 units for communication. The remaining 14 units are electives consisting of LIS (10 units), education (2 units) and reading ( 2 units). All the compulsory courses (24 units), 6 units of the required courses and the best units of the electives up to 40 units are used to compute the Weighted Average Mark to one decimal point for the award of the certificate.

Master of School Media (Academic) 
The programme is to produce candidates that will make academic career in the field of School media through research and teaching at tertiary institution's level. The programme is designed to produce qualified school media specialists with research skills to advance studies in the area of school media and teaching courses in school media at tertiary levels. Eligibility for admission into the programme is the holding of a university degree of not less than second class lower division in any discipline. Students in the school media programme will offer additional courses in information and communication technologies (ICTs), research methods and in education. The course comprises of 64 units, LIS (50 units), reading (4 units), education ( 8 units) and communication ( 2 units). The compulsory and required courses are 46 units made up of LIS (36 units), others (10 units). The remaining 18 units are electives. The course duration is similar to that of the MMRM. Candidates must pass all the compulsory courses and minimum of 35 units required for graduation.

\section{Master of Philosophy (MPhil) and Doctor of Philosophy (Ph.D.) in School Media}

The programme is for the holders of Master's degree in School Media and/or Library and Information Science. The programme consists of course work ( 8 units) and dissertation/thesis. The programme will produce high-level personnel to research into school media and teach courses in the field at the University and other tertiary institutions. Areas of research include: media in education, media services to special group, information communication technology (ICT) in school media programme, media resources, school media specialist in curriculum planning and implementation, media in distant learning programme among others. Lecturers for the programme are drawn from the fields of School Media, Library and Information Science, Education, Language, Communication and Publishing

\section{Rationale for Having an Academic Programme}

The rationale for the University in putting in place a School media Program are as follows:

- In spite of the efforts of the Nigerian Federal and State Governments to develop virile school libraries/educational resource centres for schools, very little has been achieved because the qualified personnel to organize effective school media programmes are nonexistent in the schools. Such qualified personnel have to be trained to develop effective school media programmes in schools.

- Effective school media programmes in support of schools curricula are needed to facilitate effective implementation of the 9-3-4 education system. Only qualified, dedicated and highly motivated teacher-librarians, reading-teachers and other media personnel could provide such school media programmes.

- The World Bank-Assisted Primary Education Project for Nigeria has a learning resources provision and development component. he availability of qualified media personnel can ensure the provision and effective utilization of learning resources through a virile school media programme and in effect improve the quality of education in the primary schools. Short-term workshops for teachers' in-charge of school library resource centres can not meet the challenges of this dispensation.

- In a situation where the government revenue is decreasing with corresponding decrease in budgetary allocations to schools, the part-time in-service programme will save cost of 
training the teacher-librarians, reading-teachers and other media personnel as they will not necessarily withdraw from the classrooms for the period of training, thereby necessitating the employment of additional teachers to teach their classes.

- The programme would provide further opportunities for research and direct input into the provision of relevant and suitable learning resources in the schools.

\section{Collaboration between Nigerian School Library Association and Abadina Media Resource Centre}

The Nigerian School Library Association (NSLA) was inaugurated in July 1977 and formerly launched in October of the same year. The NSLA came into existence following the consensus of opinion among the Nigerian participants at the $6^{\text {th }}$ Annual Conference of the International Association of School Librarianship (IASL) held in Ibadan, Nigeria in July 1977, that a virile, and autonomous body of School librarians capable of offering advice and influencing government policies in education as regards school library media centre is needed for the successful implementation of the Universal Primary Education (UPE) scheme, which was launched without adequate school library services to support it. It was therefore hoped that such as autonomous body would create the platform for all the stakeholders (Teacher librarians/School librarian, education officers in charge of school libraries, media specialists, educational technologists and proprietors of schools) in provision of school library services to meet and exchange views on school library development. NSLA also act in advisory capacities to government and embark on activities that promote the development of school libraries in Nigeria.

Abadina Media Resource Centre, University of Ibadan has been the secretariat for the Association since its inception in October, 1977. Thus, majority of the staff of AMRC over the years are involved in major annual planning of school library conferences in Nigeria. In addition, the Executive Secretary, the Administrative Secretary and the Treasurer are members of Staff of the Centre. Other executive members of NSLA (the President, Vice President, Financial Secretary etc) are from other affiliations in Nigeria.

\section{Benefits of the Centre to the University and the Nigerian Society}

School libraries are valuable resources for student learning and literacy. The school library exists to ensure that students and staff are effective users of ideas and information through access to resources, provision of instruction, and collaboration with teachers. Nigerian children need to read widely, enjoy reading and find the information they need from a range of sources, evaluate it, critically and synthesis their findings. Hence, the academic programme by the Centre is aimed to achieve this by producing well equipped personnel that would assist the Nigerian child in improving their reading skills. Other benefits of the Centre to the University of Ibadan and Nigeria at large include the following:

- Research studies have correlated quality school library programs to improve academic success of students regardless of the socio-economic or educational levels of the community. 
- The academic programme of the Centre is of benefit to the Nigerian educational sector because school librarians/school media specialists are pivotal to the success of literacy and reading programmes. These personnel trained at University of Ibadan would ensure that Nigerian students have opportunities to learn and develop information literacy and reading skills.

- The Centre would provide access to quality school media programmes/school library with up-to-date resources would improve the reading ability of students.

- Abadina Media Resource Centre promotes comprehensive local strategies to improve student reading achievement by improving school library services through provision of adequate resources. It also proposes to improve information literacy skills and academic achievement by providing students with increased access to up-to-date school library materials, a well-equipped, technologically advanced school library media centre managed by well-trained, professionally certified school library media specialists.

- The provision of school library media center and the development of reading habits supported by the Centre will provide avenue for Nigerian children to engage in meaningful intellectual development which would draw them away from crime. Knowing how to learn from mistakes through reading and becoming a responsible citizen are some of the gains.

\section{Photo Speaks \\ Before going into the challenges faced by the Centre, I would want to take us through some pictures that projects past and recent creatives of the Centre especially in a developing economy. [See Appendix]}

\section{Challenges faced for the Centre}

Major challenges facing AMRC could be divided into two sections

- The Building Extension

The growing population of users of our model school library as well as the introduction of the academic programmes has led to the recruitment of more staff and increased number of students which has necessitated the need for the extension to the old building. The extension to the building would take care of staff offices, lecture rooms/conference/seminar rooms and resource centre for postgraduate students, among others. The pressure on the existing building (used since 1974 ) is such that there is space crisis for the SLMC to operate effectively.

The extension would be a relief to the burden of space crisis on the existing building. Having additional building extension would provide ample space for the SLMC to cater for the specialized unit such as Toy/Play room, reading room for nursery, primary school users and the reading room for upper primary and young adults.

- Model School Library Resource Collection

The funding of the Centre hitherto is mainly from the University budget. The internally generated resources are minimal since the teaching programme has just commenced. With the sharp cut in budget experienced over time, the Centre has not got access to adequate fund to meet the demand of its programmes. For instance, the Centre cannot develop up to date and adequate collection, purchase an operational vehicle, computers for staff and students' use and fund 
library automation. Efforts made at generating revenue internally to help the Centre have been frustrated for lack of fund to meet initial expenses for planning.

Provision of adequate and relevant books and non-books materials is also one of the major challenges confronting the centre. This is having negative impact on both the Centre and the users. The Centre has to contend with the issue of rationing books, among users while the users has to contend with the issue of having to wait more than necessary before having access to the book that interest them. However, the centre has been doing what it could over the years through purchase of new books, but the meager amount available for purchase is really a major constraint. Of recent, the centre made effort at improving on the library collection by soliciting for support in form of donation of books from book publishers but the effort has not yielded any positive result.

\section{Conclusion}

Reading habits among Nigerian children are on the decline as it is happening around the world, hence there is a need for Nigerian government to build and equip libraries for primary and secondary schools and make them attractive with regular creative fun programmes that would assist in the inculcating reading habits and library use. Improving library services in schools is essential in building the reading culture of Nigerian children which would translate to improved academic achievement. Establishing a state-of-the-art school library has a critical function in every school to support, engage and stimulate learning and development in this Second Millennium digital (IASL and IFLA document on School Library Proclamation, 2010). Abadina Media Resource Centre was able to create innovations in school library services in Nigeria because of the favorable environment created by the University of Ibadan despite the economic recession in the country which had affected the University. The University could readjust her monitory policies and make sure that the children's library it better funded in order to make way for more creativity that would lead to equipping Nigerian children with information literacy and reading skills. I end my submission by quoting Peter Beauchamp Chief Library Adviser, Department for Culture, Media and Sport, UK as saying

"The school library is a vital component in addressing the Government's agenda of raising educational achievement. The library provides a stimulating environment with a wide range of multi-media resources that encourage even the youngest pupils to develop reading skills and discover that learning can be fun. In doing this, the library not only supports the formal curriculum but, by promoting learning for pleasure, lays the foundation for a lifetime of learning" (CILIP, 2002)

\section{References}

Abadina Media Resource Centre. (2010) Budget Proposal for Abadina Media Resource Centre. Ibadan: University of Ibadan. Unpublished material.

Abadina Media Resource Centre. (2011) Prospectus. Ibadan: University of Ibadan. Unpublished material.

CILIP (2000). The Primary School Library Guidelines. Retrieved March 14, 2012 at http://librarynext.files.wordpres.com/2000 
Elaturoti, D. F. (2007). David Folorunso Elaturoti Biography: Abadina Media Resource Centre. Retrieved March14, 2012, at http://dave-elaturoti.faithweb.com/abadina.htm

Elaturoti, D. F. (2007). Education and Training of School Library Media Specialists for the Nigerian Schools in the 21st Century: The Abadina Media Resource Centre Programme. Nigerian Library Association 45th National Conference. Retrieved March10, 2012, at http://www.nla-ng.org/uyo2007compedium.pdf

IFLA/UNESCO (2006). School Library Manifesto: The School Library in Teaching and Learning for All. Retrieved February 2, 2012, at from http://www.ifla.org/

Mahajan, p (2010) School Libraries in India: Present-day Scenario. Library Philosophy and Practice . Retrieved May 23, 2012 www.webpage.uidaho.edu/mbolin/mahajan5.htm

School Library Works (2008), Research Foundation Paper. Retrieved March14, 2012, at www.scholastic.com/librarypublishing

University of Ibadan Distance Learning Centre (2010) Diploma in School Media Programme Retrieved March 10, 2012, at http://degree.dlc.ui.edu.ng/dlc/prospectus/diploma/school_media.pdf

\section{Authors Note}

Fadekemi Omobola OYEWUSI is the Acting Director of Abadina Media Resource Centre, University of Ibadan, Nigeria. She is also a Senior Research Fellow in the University of Ibadan with research interest in information literacy, reading attitude, media resources and school libraries.

Fadekemi Oyewusi obtained her Master Degree and PhD in Library Studies from University of Ibadan. She is currently the Treasurer of Nigerian School Library Association (NSLA). 


\section{Appendix}

\section{Photo Speaks}

\section{Picture Portraying the Activities of AMRC}

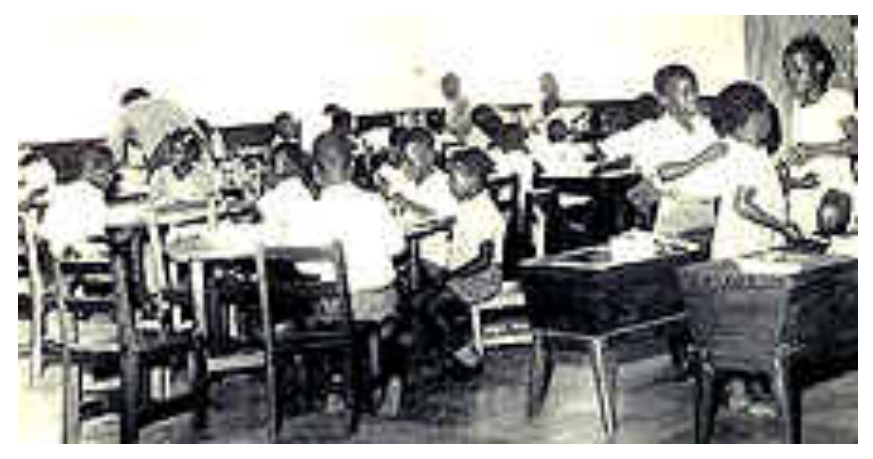

Library users in AMRC in 1980

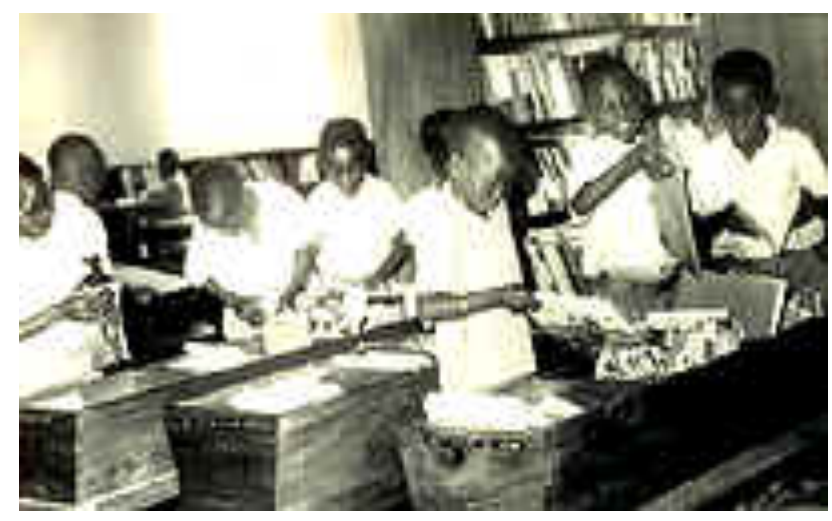

Library users in AMRC in 1980 


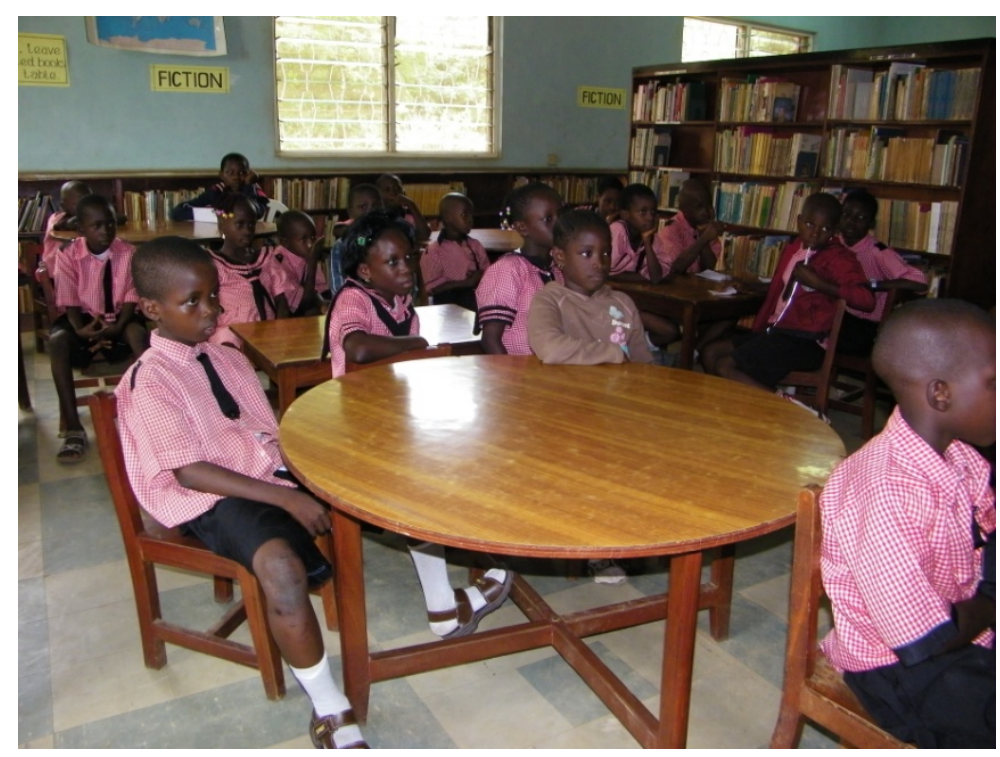

Library users in AMRC in 2011

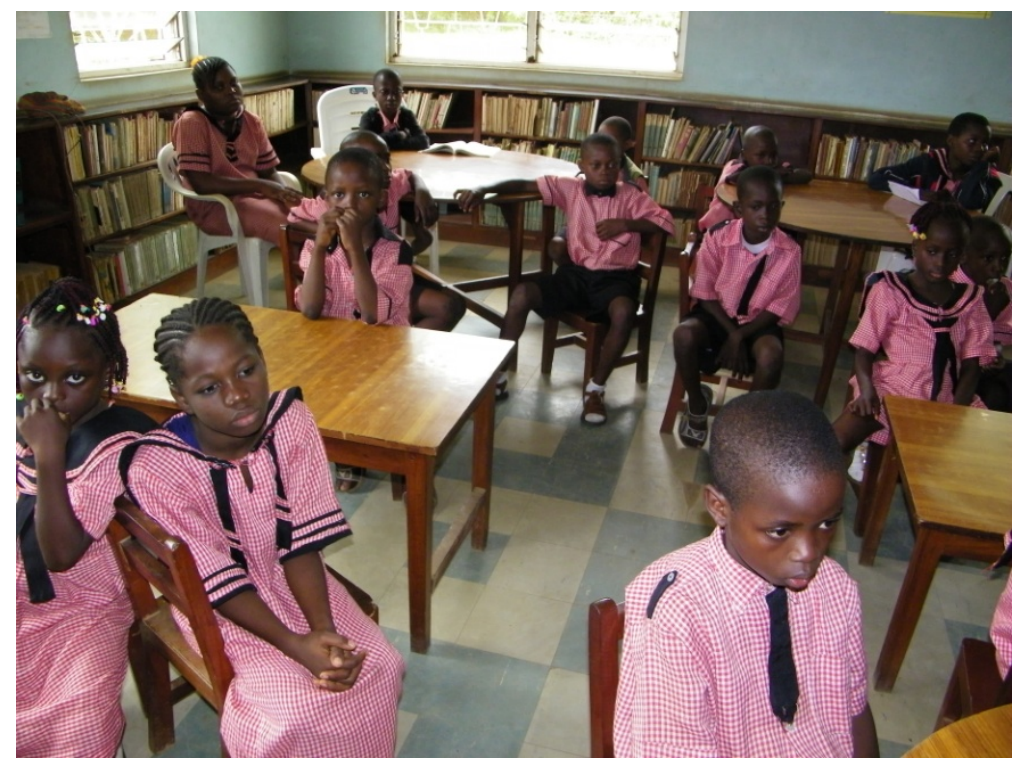

Library users in AMRC in 2011 


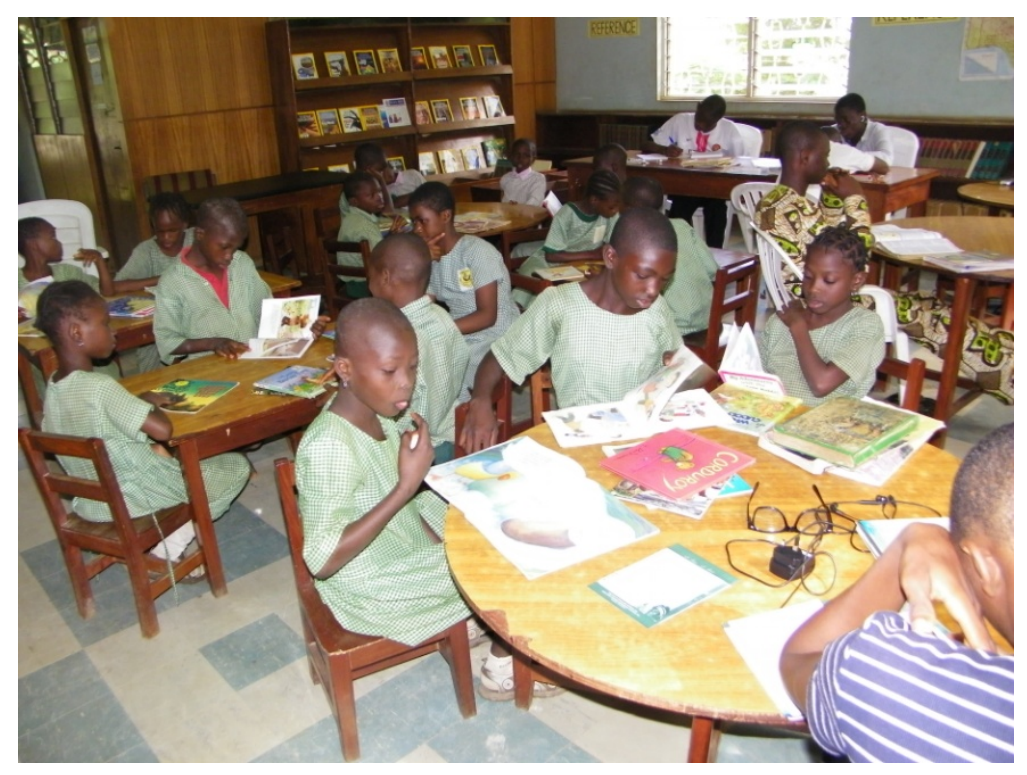

Library users in AMRC in 2010

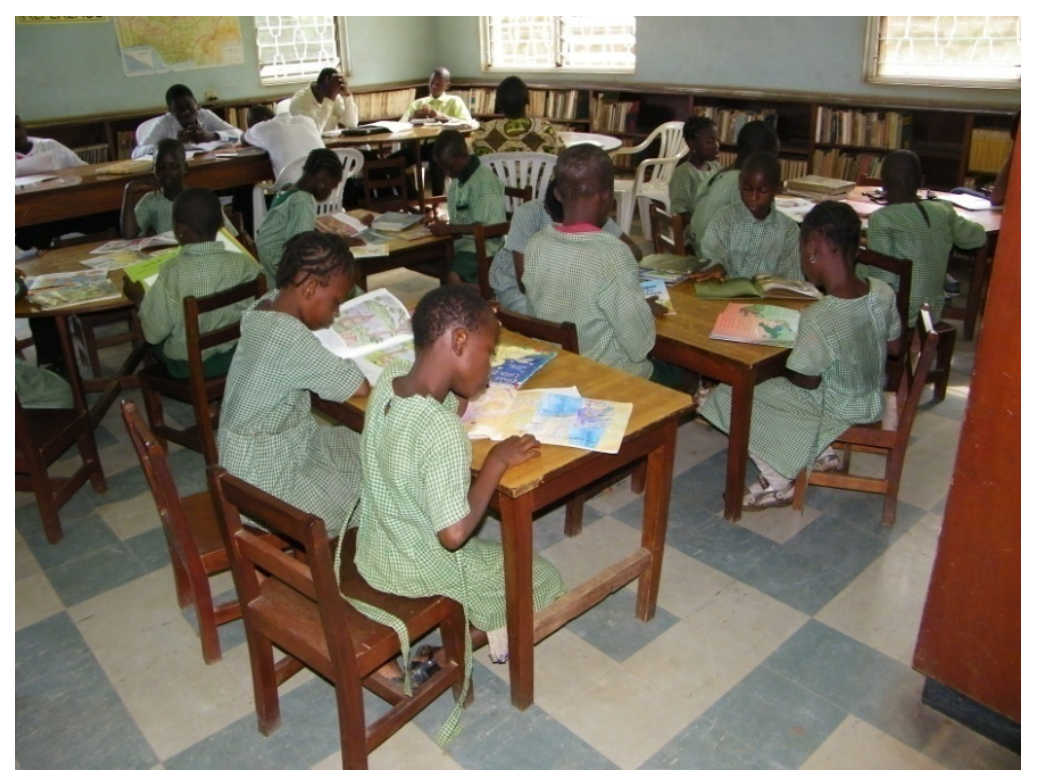

Library users in AMRC in 2010 


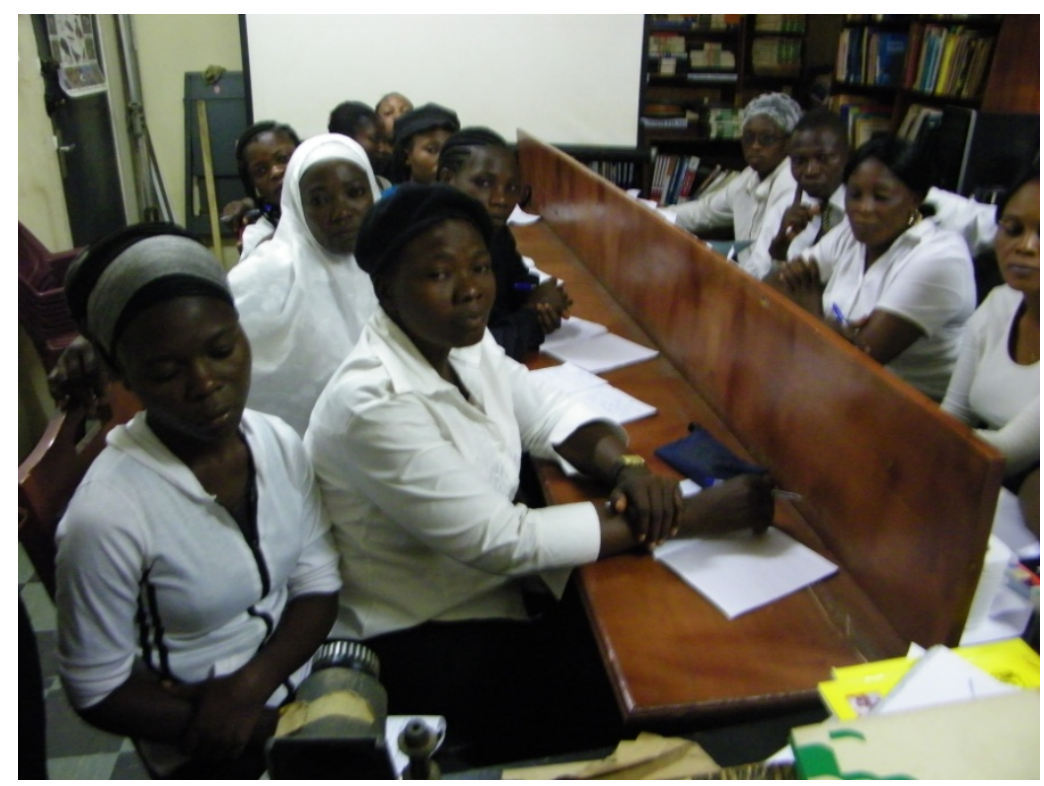

Degree students from Department of Library, Archival and Information, University of Ibadan on school library Visit

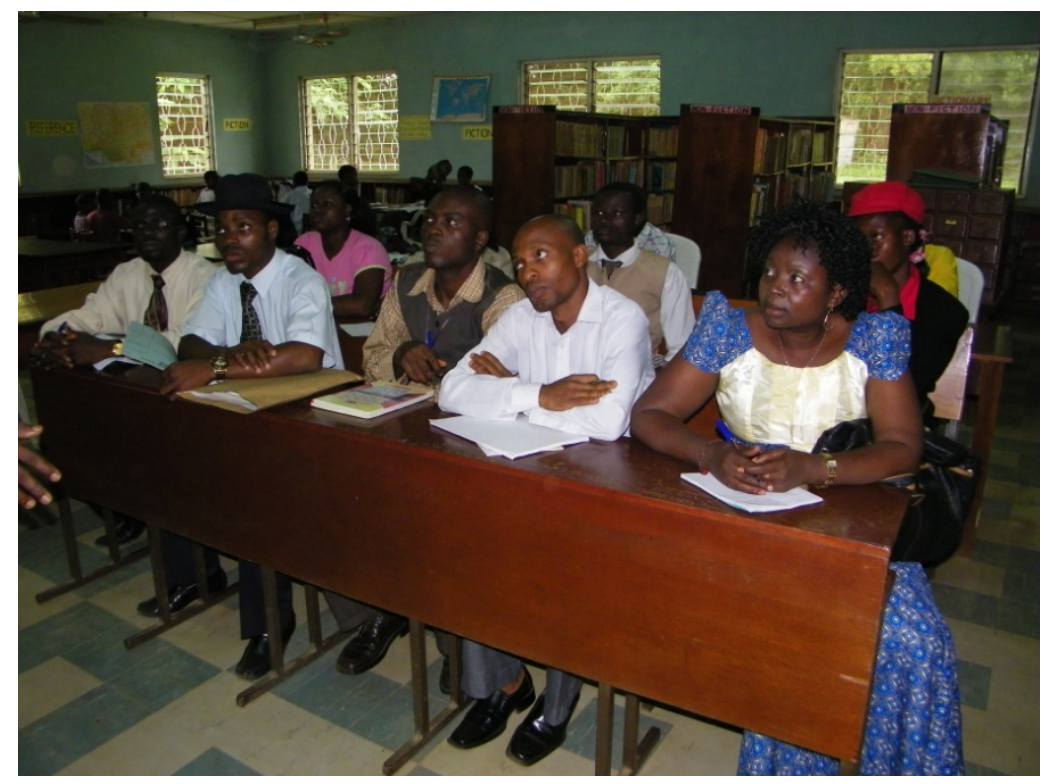

Degree students from Department of Library, Archival and Information, University of Ibadan on school library Visit 


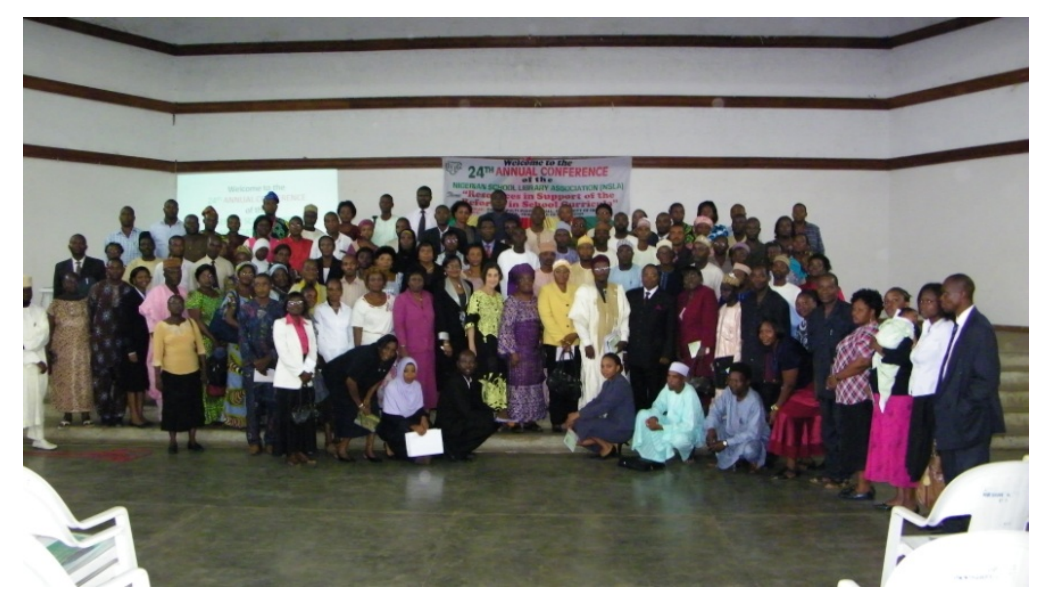

NSLA conference at University of Ibadan 2009

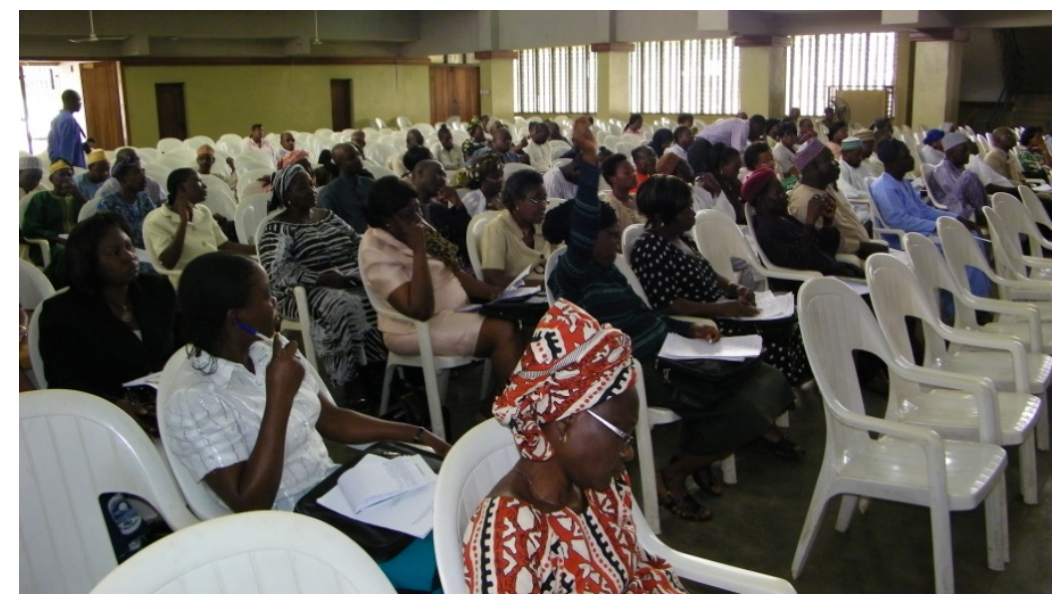

NSLA conference at University of Ibadan 2009 


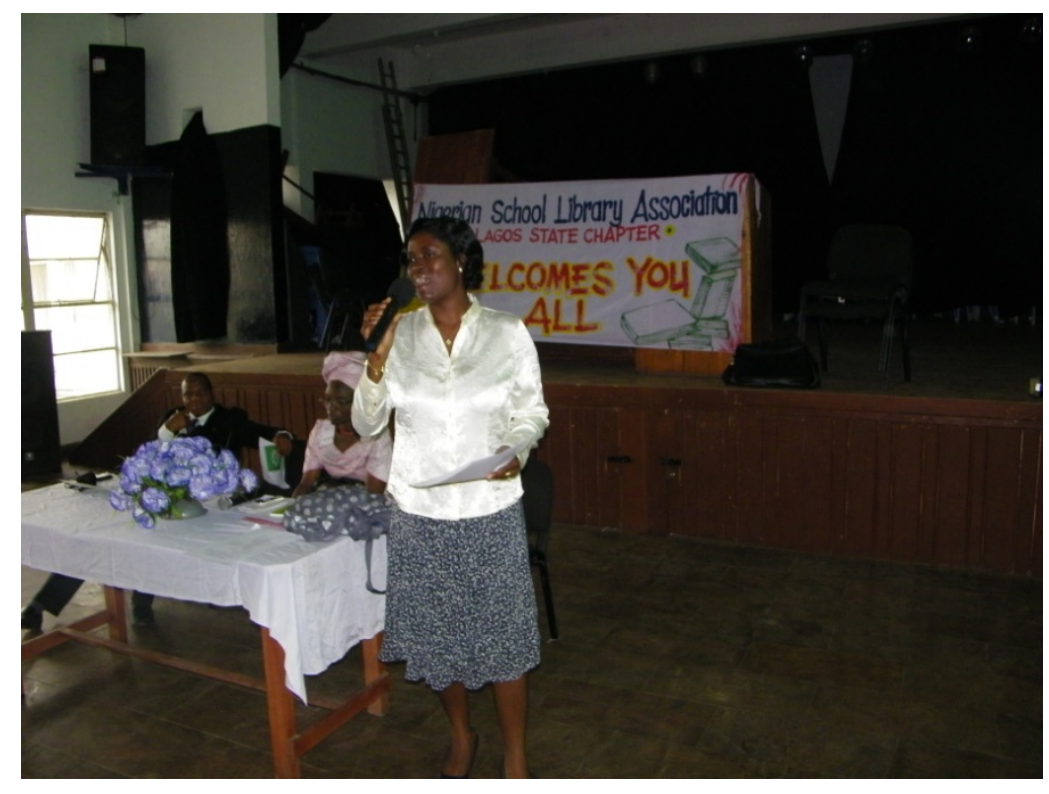

Workshop for teacher Librarians at Lagos State Chapter of NSLA 2010

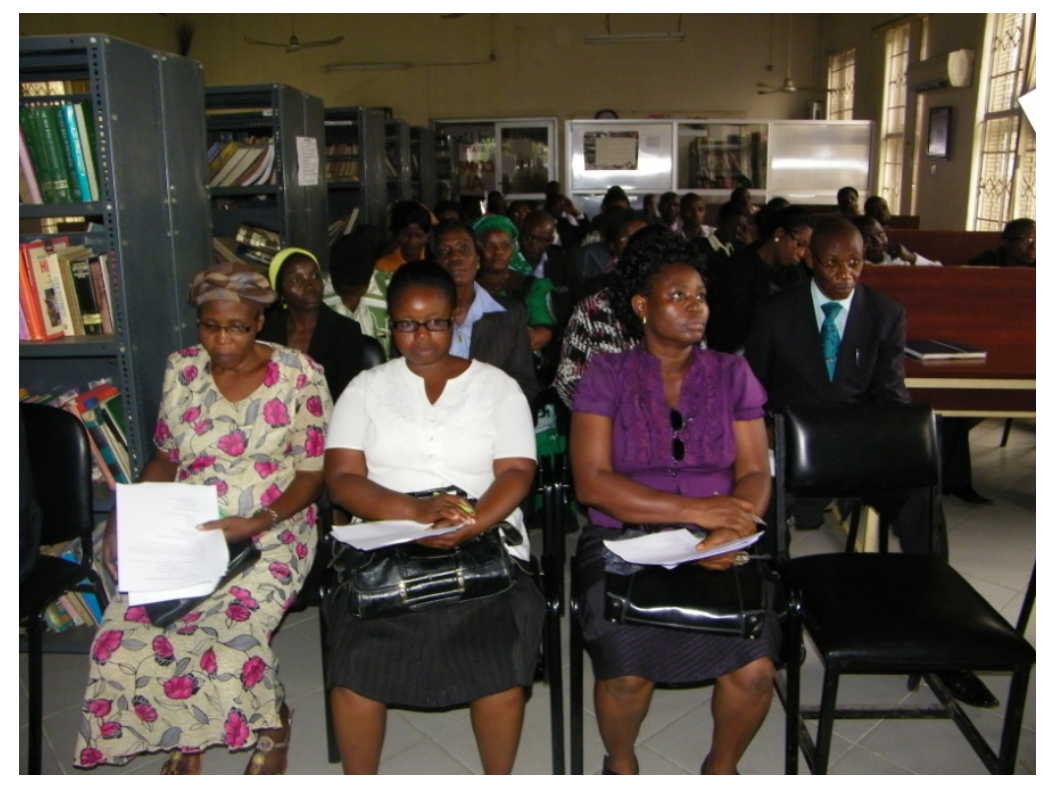

Workshop for Teacher Librarians at Lagos State Chapter of NSLA 2010 


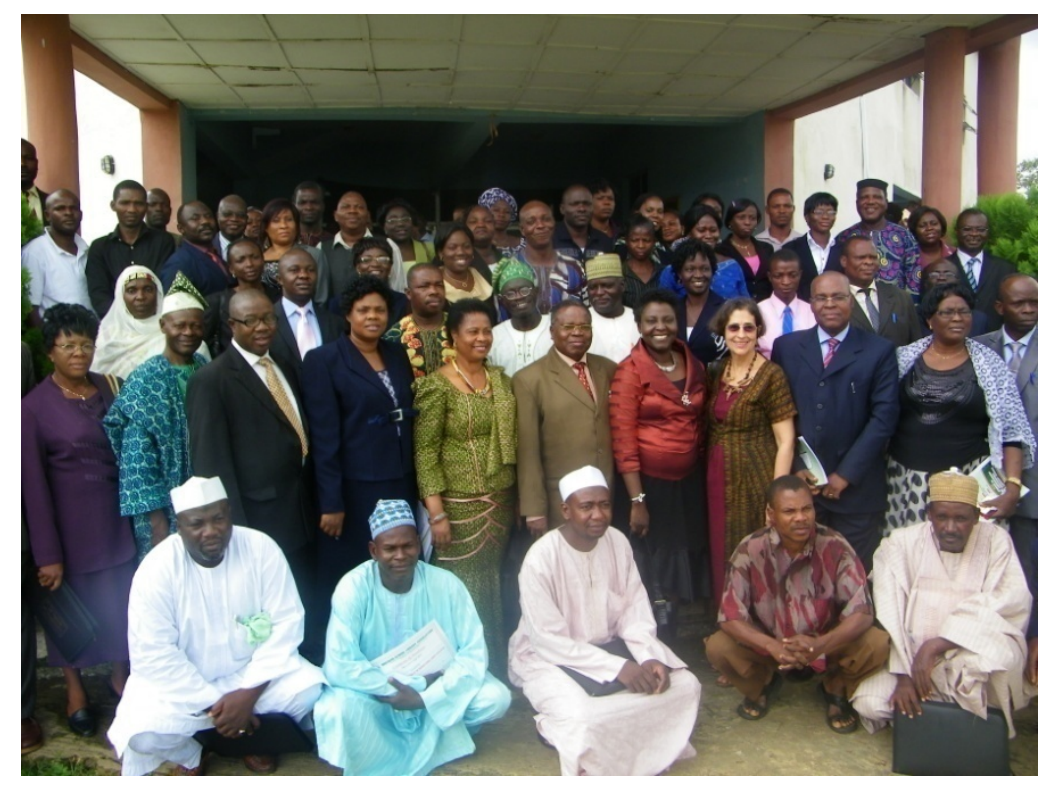

NSLA2011 Conference at Ekiti State, Nigeria

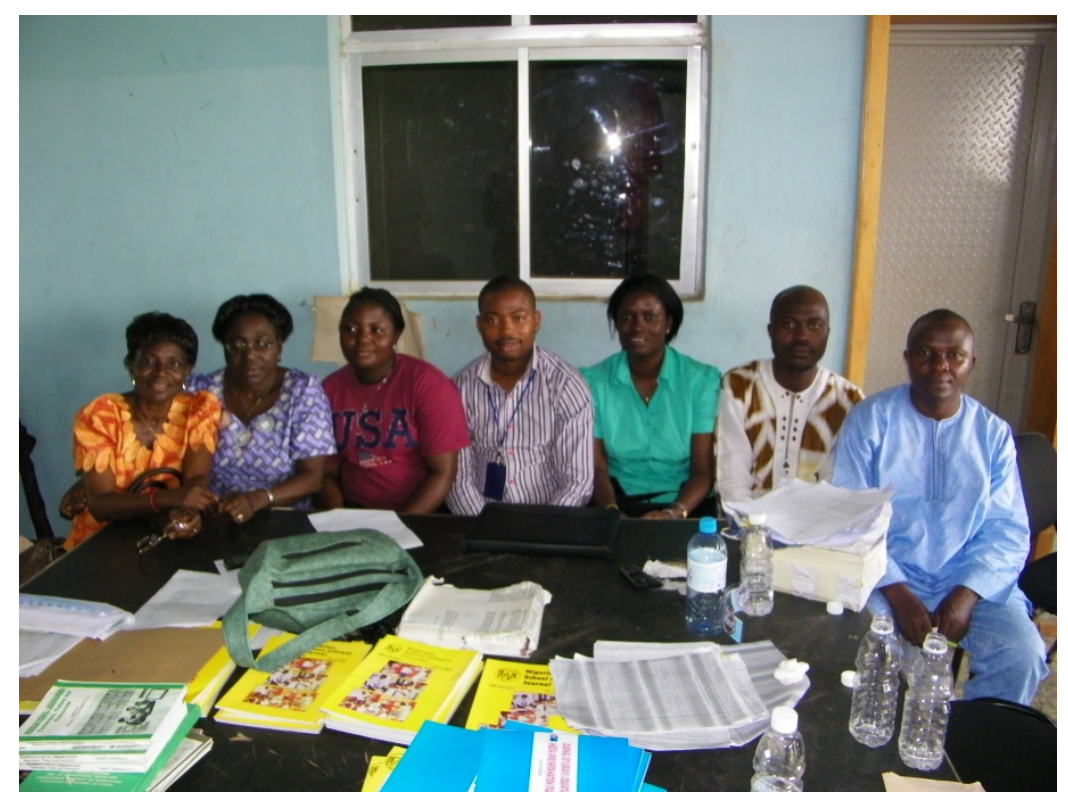

AMRC Staff as Conference Organisers at NSLA2011 Conference at Ekiti State, Nigeria 


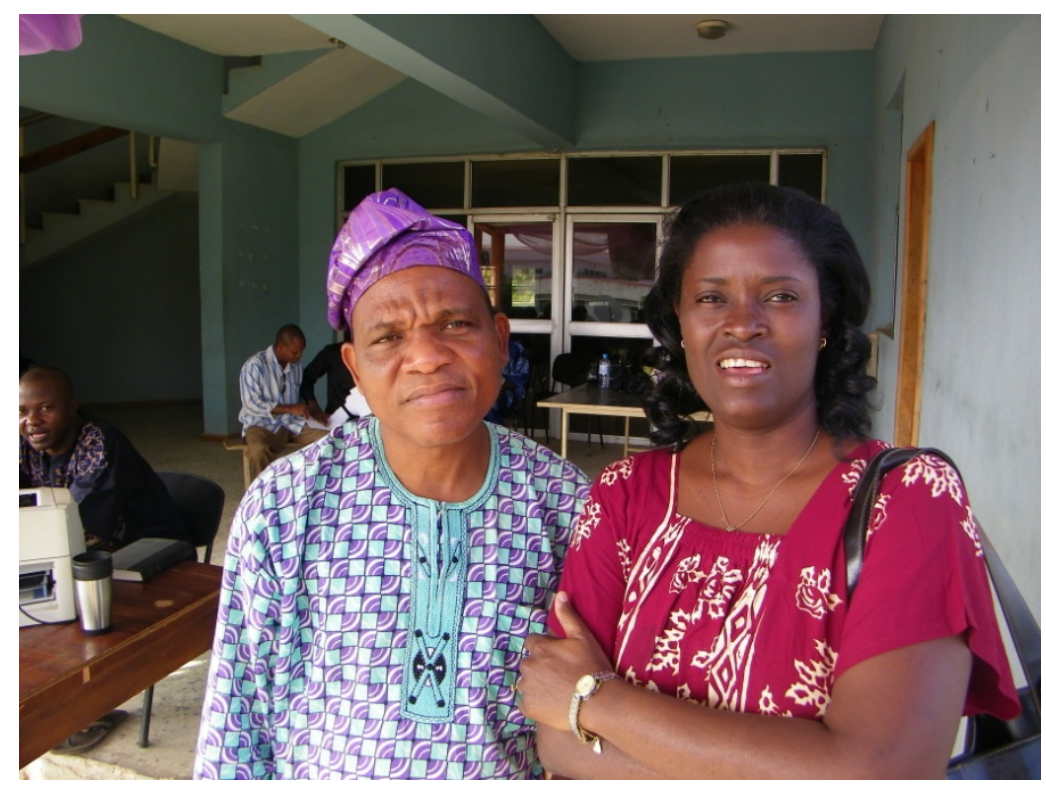

AMRC Staff as Conference Organisers at NSLA2011 Conference at Ekiti State, Nigeria

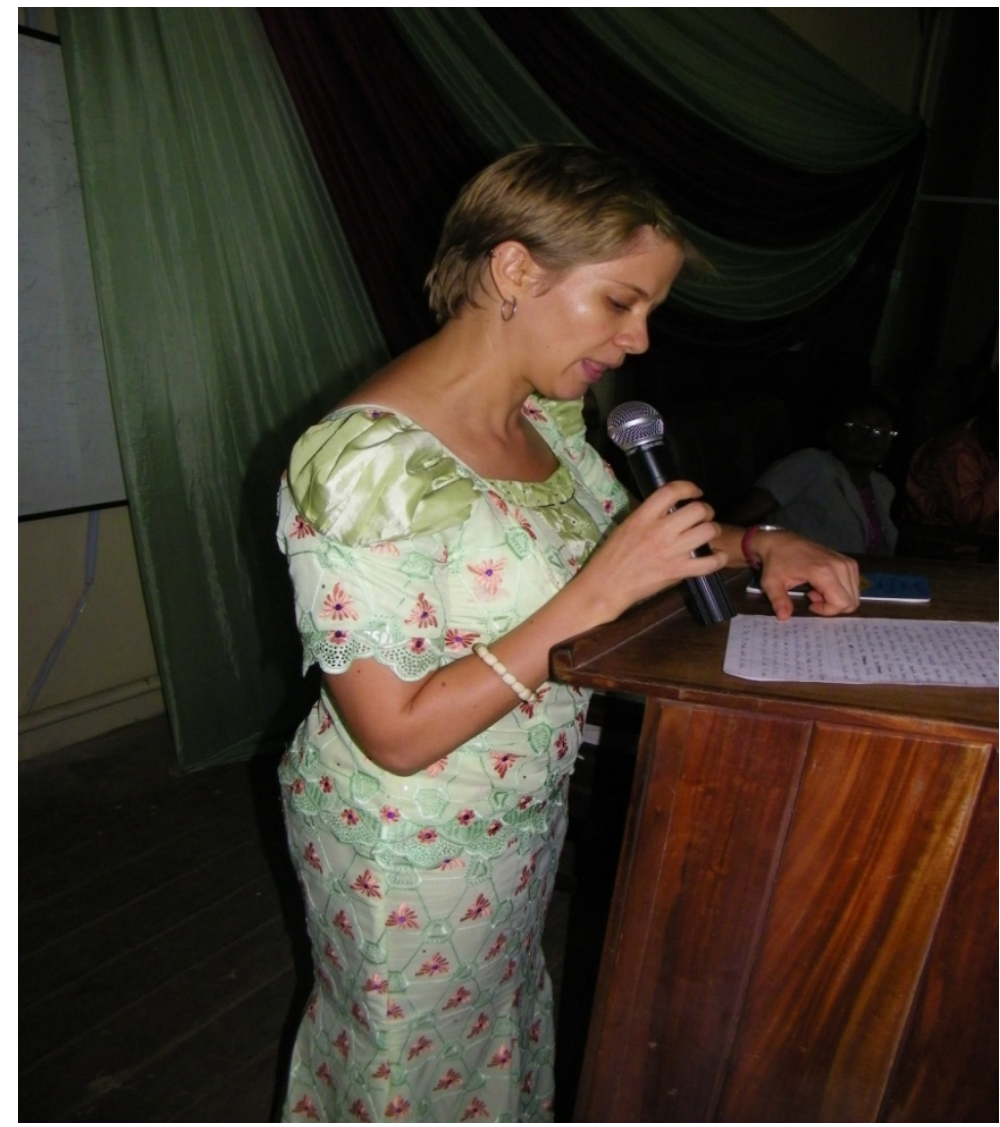

Naomi Moland PhD Student From NYU at Reading Culture Seminar organized by AMRC 2011 


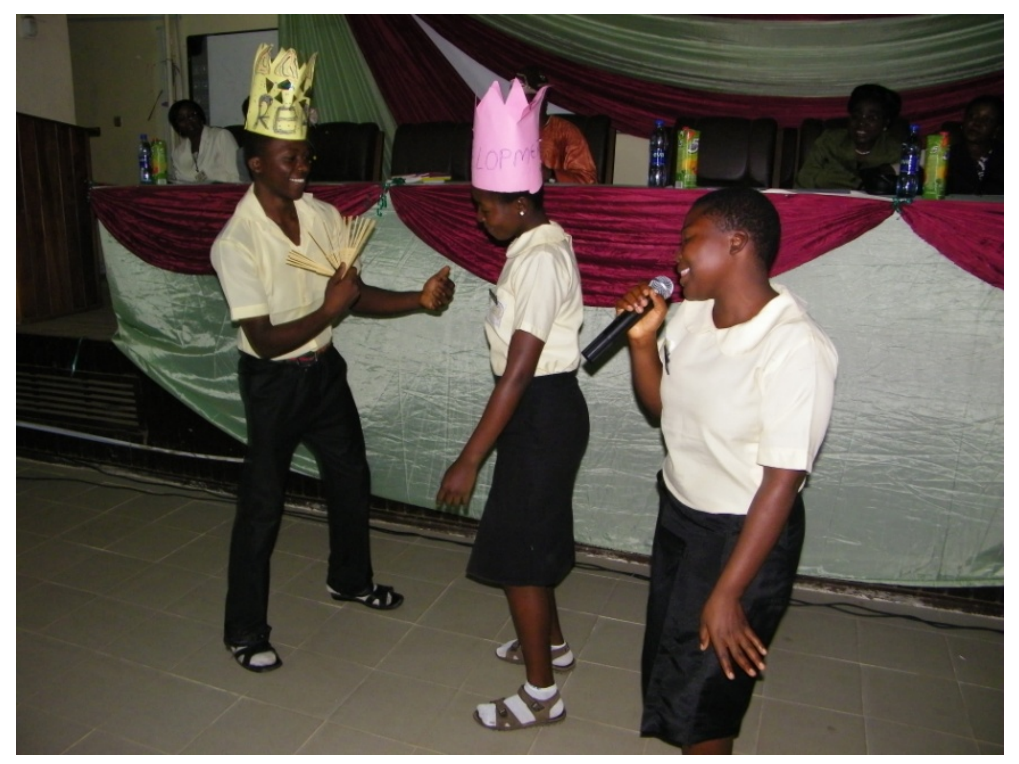

Students acting drama on the importance of reading at Reading Culture Seminar organized by AMRC 2011

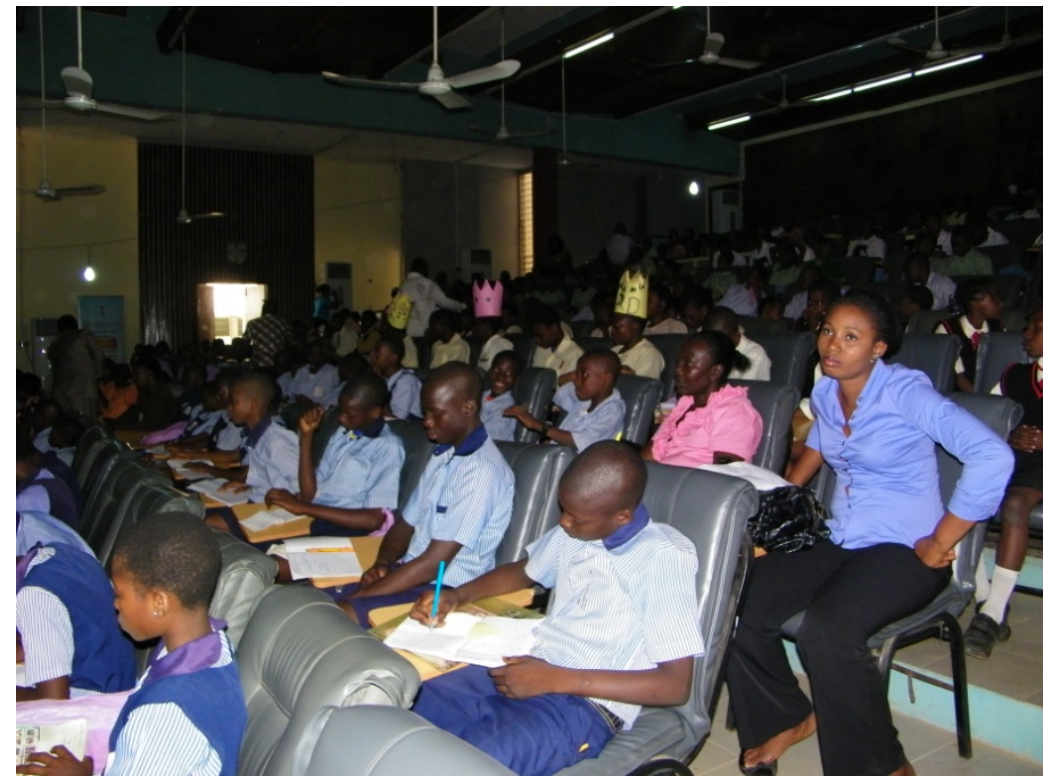

School Children at Reading Culture Seminar 2011 


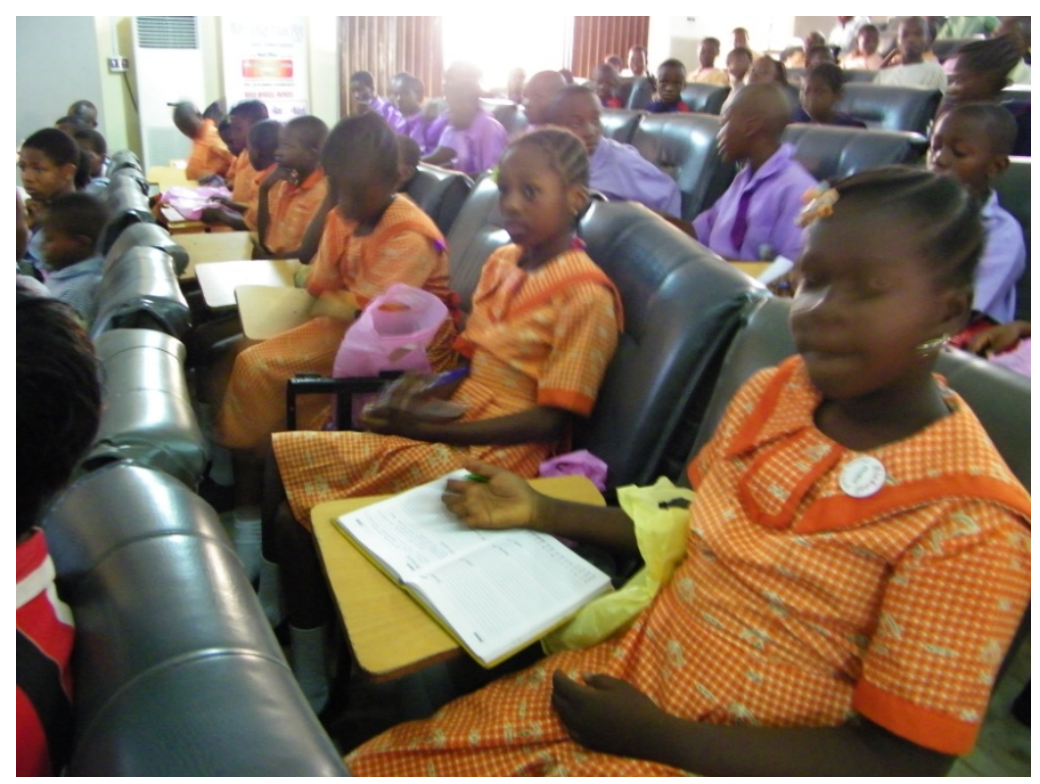

School Children at Reading Culture Seminar 2011

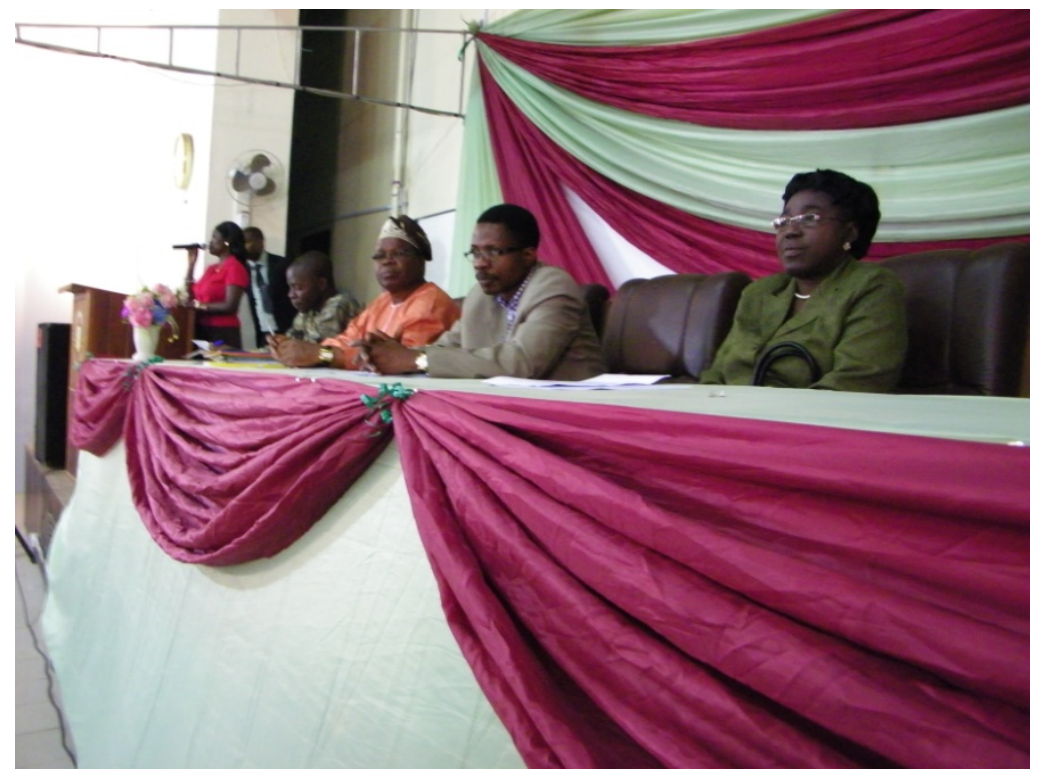

Officials of University of Ibadan at Reading Culture Seminar 2011 


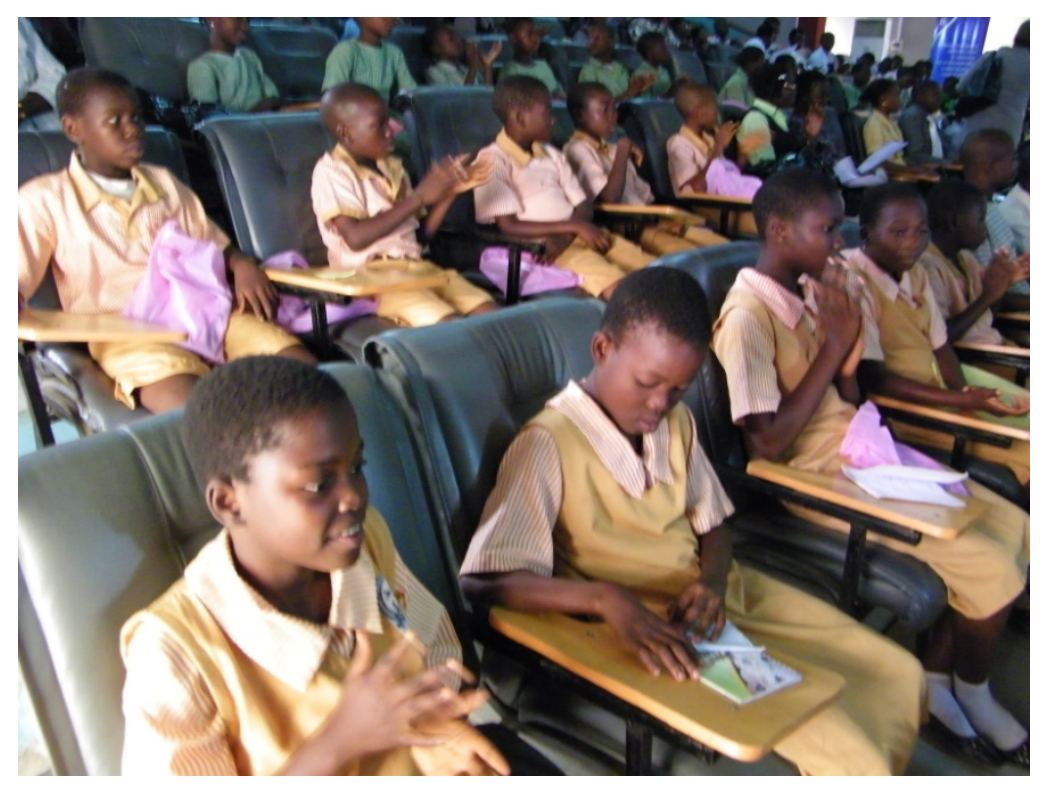

School Children at Reading Culture Seminar 2011

\section{US Consulate IRO Visits Abadina Media Resource Center, University of Ibadan}

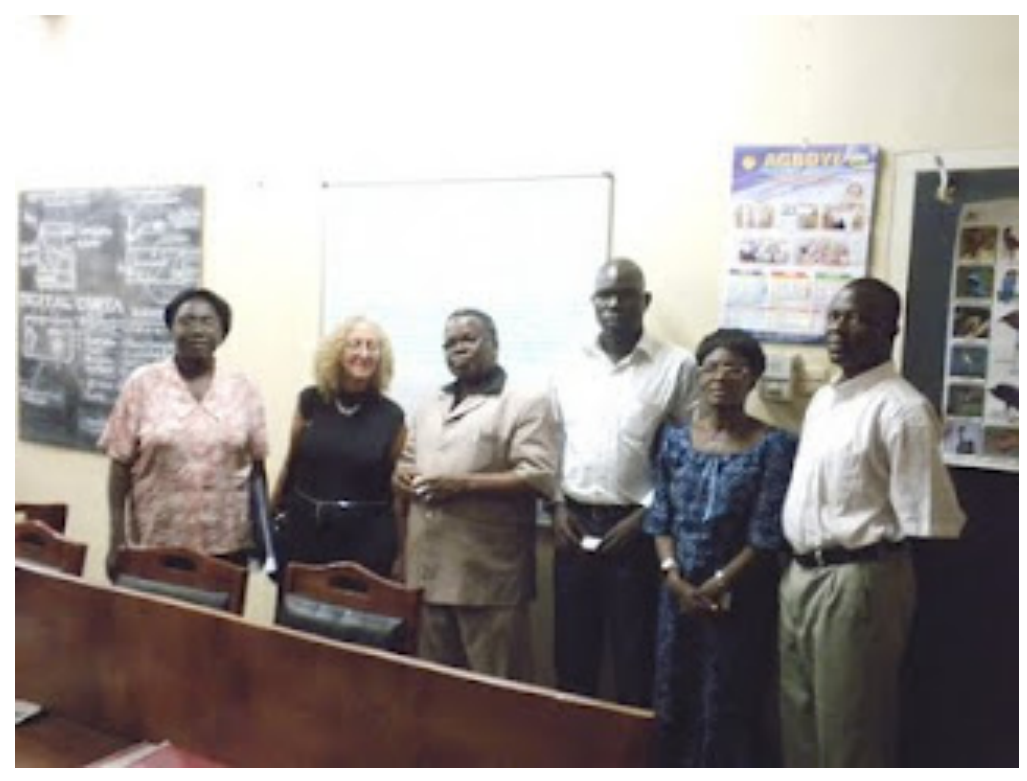

IRO-Suzanne Miller (2nd left) with some members of staff of

Abadina Media Resource Center, University of Ibadan during her visit to the popular city. 


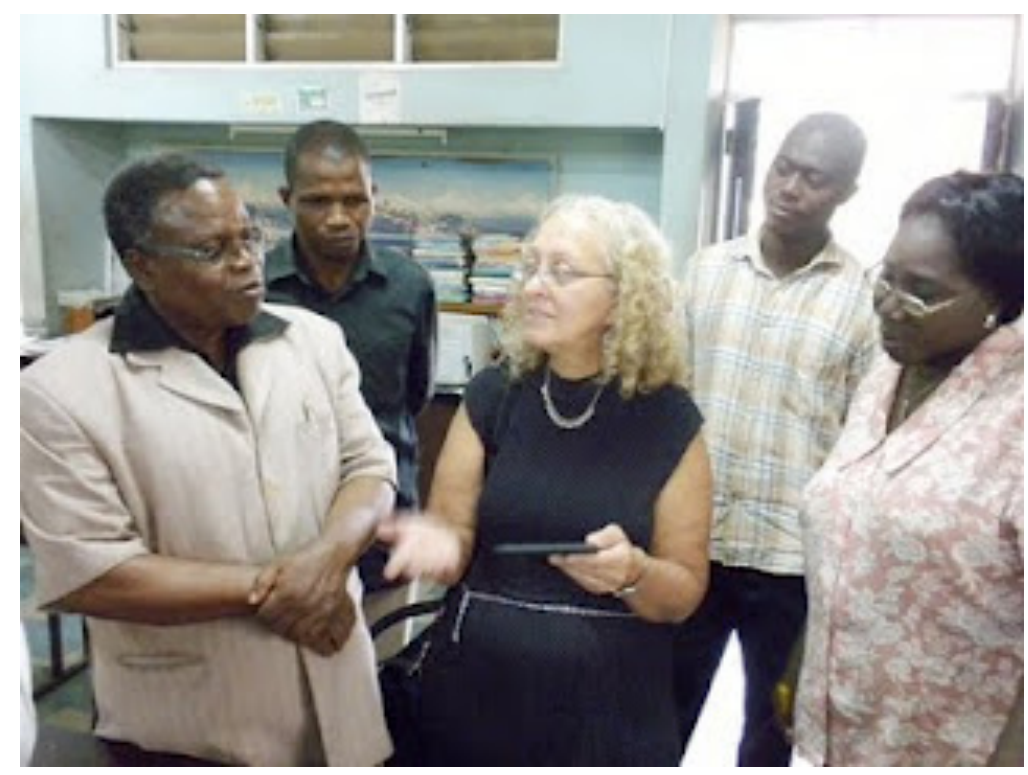

IRO-Suzanne Miller (center) discusses the use of Kindle with staff of Abadina Media Resource Center, University of Ibadan. Listening is Professor David Elaturoti (left) and Mrs. Helen Kolade (right) - the Acting Director of the Center on Wednesday, May 18, 2011

Culled from: http://documentsondesk.blogspot.com/2011/05/iro-visits-abadina-media-resource.html 